\title{
Rasio Penutupan Luka pada Tikus Diabetes Diinduksi Streptozotocin dengan Perlakuan Dressing Tipe Pasif dan Interaktif (Penelitian Pendahuluan)
}

\section{Wound Closure Ratio in Streptozotocin-Induced Diabetic Mice Treated by Passive and Interactive Dressing (Pilot Study)}

\author{
EKO NANING SOFYANITA* \\ ARYA ISWARA** \\ Jurusan Analis Kesehatan Poltekkes Kemenkes Semarang* \\ Jl. Wolter Monginsidi Pedurungan Tengah Semarang \\ Fakultas Ilmu Keperawatan dan Kesehatan Universitas Muhammadiyah Semarang** \\ Jl. Kedungmundu Raya No. 18 Tembalang Semarang \\ Email: en.sofyanita@gmail.com
}

\begin{abstract}
Abstrak
Luka diabetes memerlukan waktu penyembuhan yang lama dan sulit dalam penanganannya. Proses penyembuhan luka adalah dengan prinsip mempertahankan dan menjaga lingkungan luka tetap lembap, serta mempertahankan kehilangan cairan jaringan dan kematian sel. Metode perawatan luka yang sedang berkembang saat ini berpegang pada prinsip moisture balance disebut dengan modern wound dressing. Penelitian dilakukan pada mencit C57BL/6j yang dilukai dan diberi dua tipe dressing yaitu hydrocolloid dan gauze dalam penanganan luka diabetes pada mencit. Hasil pengamatan perlakuan perawatan luka menunjukkan hasil akhir penyembuhan luka yang berbeda satu sama lain. Ukuran luka kelompok hydrocolloid yang makin membesar sampai pada hari ke-3 dan ukuran luka lebih besar di hari ke 21 bila dibandingkan dengan kelompok gauze. Diperkuat dengan perbedaan secara statistik $(p=0.001)$. Kedua kelompok membantu dalam proses penyembuhan luka namun perlakuan dressing hydrocolloid dan gauze memiliki dampak yang berbeda bagi penyembuhan luka.
\end{abstract}

Kata Kunci : Luka ; Diabetes ; Hydrocolloid ; Gauze

\begin{abstract}
Diabetic wounds are slow to heal, are difficult to manage. Wound healing should retain the wound area humidity, and prevent the skin from fluid loss and cell death. The recent wound care is using moisture balance principal using modern wound dressing. This research was conducted in C57Bl/6j wound and treated by hydrocolloid and gauze dressing. The results were different for each group. The wound size of hydrocolloid dressing became bigger until day 3 and the wound size was bigger until day 21 compared to gauze group. The difference is also statistically different $(p=0.001)$. Both hydrocolloid and gauze groups shows result on helping the wound healing but have a different effect on wound healing.
\end{abstract}

Keywords: Wound ; Diabetes ; Hydrocolloid ; Gauze

\section{Pendahuluan}

Diabetes Melitus tipe II (DM Tipe II) merupakan penyakit metabolik yang ditandai dengan hiperglikemia yang diakibatkan oleh kegagalan sekresi insulin di dalam tubuh, kerja insulin atau keduanya (Gunardi, 2020). Hal ini yang akan menyebabkan kerusakan pembuluh darah sehingga akan berpengaruh terhadap jantung, mata, ginjal, dan saraf (Imawati, 2020). Kondisi hiperglikemia pada diabetes disebabkan oleh adanya kegagalan pengaturan glukosa darah, kegagalan pengaturan inilah yang menjadi kunci hubangan diabetes denga komplikasi diabetes, salah satunya adalah luka diabetes. Luka diabetes memerlukan waktu penyembuhan 
yang lama, sulit dalam penanganannya serta luka dapat bertahan dalam hitungan minggu, bulan bahkan tahun. Hal tersebut yang menjadikannya perhatian khusus dalam proses penyembuhan luka diabetes (Oguntibeju et.al, 2019).

Penyembuhan luka terdiri dari fase-fase yang kompleks dan melibatkan banyak sel. Fase-fase tersebut meliputi; koagulasi, inflamasi, proliferasi, dan fase remodeling (Darmawati et al. 2021). Proses penyembuhan luka pada diabetes akan banyak mengalami perubahan fase karena adanya kondisi hiperglikemia yang dapat menyebabkan komplikasi kronis (Tan, et.al., 2019). Perlambatan penyembuhan luka disebabkan oleh beberapa faktor seperti lebih lamanya tahap inflamasi, terhambatnya proliferasi dan remodeling (Landen, et.al., 2016)

Proses penyembuhan luka adalah dengan prinsip mempertahankan dan menjaga lingkungan luka tetap lembap, serta mempertahankan kehilangan cairan jaringan dan kematian sel. Metode perawatan luka yang sedang berkembang saat ini berpegang pada prinsip moisture balance disebut dengan modern wound dressing (Kartika, 2015). Dressing pada luka umumnya berbahan dasar polimer sintetis dan dapat diklasifikasikan dalam dressing passive, interaktif dan bioaktif. Produk dressing tipe pasif bersifat non-oklusif, yang termasuk di dalamnya adalah gauze dan tulle dressing, memiliki fungsi untuk menutup luka dan mengembalikan fungsi mekanisme dari luka yang ditutupinya. Sifat tersebut berbeda dengan dressing tipe interaktif yang bersifat semi-oklusif atau bahkan terkadang oklusif, yang termasuk dressing tipe ini antara lain adalah films, foam, hydrogel dan hydrocolloid. Dressing ini lebih bertindak sebagai pelindung dari serangan bakteri ke area luka (Hunt et al 2000; Rivera \& Spencer, 2007; Strecker-McGraw et al, 2007).

Berdasarkan latar belakang tersebut maka peneliti merasa perlu untuk melakukan penelitian pada dua tipe dressing yaitu hydrocolloid dan gauze dalam penanganan luka diabetes dengan model hewan coba.

\section{Metode}

Penelitian ini menggunakan 12 mencit jantan galur murni C57BL/6j yang dibagi menjadi 2 kelompok, yaitu kelompok luka dengan perlakuan dressing Hydrocolloid (HC), dan kelompok luka dengan perlakuan dressing Gauze (GZ). Sebelum dilakukan pembuatan kondisi diabetes, tikus mendapatkan waktu aklimatisasi di laboratorium selama 7 hari dan dipelihara dalam kandang individual agar menghindari mencit untuk saling melukai. Tikus mendapatkan makan dan minum secara ad libitum dan siklus 12 jam terang dan geap. Kandang mencit dibersihkan dan melakukan penggantian bedding (serutan kayu) setiap 2 hari. Pembentukan kondisi diabetes dilakukan setelah proses aklimatisasi. Tahap awal dilakukan dengan pemeriksaan kadar gula darah mencit dengan mengambil darah dari vena pada bagian ekor dan diperiksa menggunakan stik pemeriksaaan glukosa. Mencit diinduksi secara intraperitoneal dengan streptozotocin dosis $120 \mathrm{mg} / \mathrm{kg} / \mathrm{BB}$. Gula darah diperiksa selama 1 minggu sampai nilai kadar gula darah stabil tinggi $(<400 \mathrm{mg} / \mathrm{dL})$. Pemeriksaan gula darah juga dilakukan setiap hari selama perlakuan dressing sampai hari mencit dikorbankan untuk pemastian kondisi diabetes.

Bagian dorsal mencit dicukur dengan menggunakan clipper untuk menghilangkan rambut sehingga nampak bagian kulit tempat pembuatan luka. Luka dibuat pada kanan dan kiri bagian dorsal dengan menggunakan biopsy punch ukuran $4 \mathrm{~mm}$ sehingga tiap mencit memiliki dua buah luka. Perlakuan dressing langsung diberikan pada hari pembuatan luka (hari ke-0). Tiap luka ditutup secara menyeluruh dengan menggunakan dressing hydrocolloid maupun gauze. Luka dibersihkan dan dilakukan penggantian dressing setiap hari.

Pengamatan dan pengukuran luka dilakukan setiap hari dengan mengambil foto luka dengan kamera serta menggunakan polypropylene sheet untuk mengukur luas luka selama 21 hari.

Rasio area luka dilakukan dengan bantuan software komputer ImageJ, dengan membandingkan ukuran awal luka dengan ukuran tiap hari perlakuan. Hasil penghitungan 
rasio area luka disajikan dalam bentuk grafik dan dianalisis dengan uji independent T-test menggunakan SPSS ver.25.

\section{Hasil dan Pembahasan}

Oguntibeju (2019) menyatatakan bahwa luka diabetes akan memerlukan waktu yang lebih lama dalam penyembuhan. Tertundanya penyembuhan dikarenakan gangguan metabolisme pada penderita diabetes serta perubahan fase penyembuhan yang tidak sesuai seperti seharusnya. Penelitian ini menunjukkan hasil yang sama, pada tikus diabetes memerlukan waktu yang lebih panjang untuk sampai membuat luka tertutup. Penelitian yang dilakukan selama 21 ini hari memperlihatkan rata-rata luka yang tidak tertutup sempurna, hal ini membuktikan bahwa luka kondisi diabetes belum dapat menutup sempurna seperti halnya pada kondisi normal (tanpa diabetes) yang hanya memerlukan waktu 14 hari untuk menutup.

Luas luka berfungsi untuk mengetahui keadaan luka secara makroskopik, dimana luas luka ini menunjukkan perubahan luka, apakah dressing yang digunakan ada perbedaan dalam proses pengecilan luka. Perlakuan luka dengan menggunakan hydrocolloid dan gauze menunjukkan hasil akhir yang berbeda satu sama lain dan dapat dilihat pada (gambar 1), sedangkan grafik perbadingan rasio area luka pada perlakuan dressing hydrocolloid dan Gauze pada (gambar 2) sebagai berikut :

Gambar 1. Foto area luka pada perlakuan hari ke 0 sampai hari ke-21. (Scale bar: 5 milimeter)

\begin{tabular}{|c|c|c|c|c|c|}
\hline & Hari 0 & Hari 3 & Hari 7 & Hari 10 & Hari 1 \\
\hline Hydro & & & & & \\
\hline Gauze & & & & & \\
\hline
\end{tabular}

Gambar 2: Grafik perbadingan rasio area luka pada perlakuan dressing hydrocolloid dan Gauze

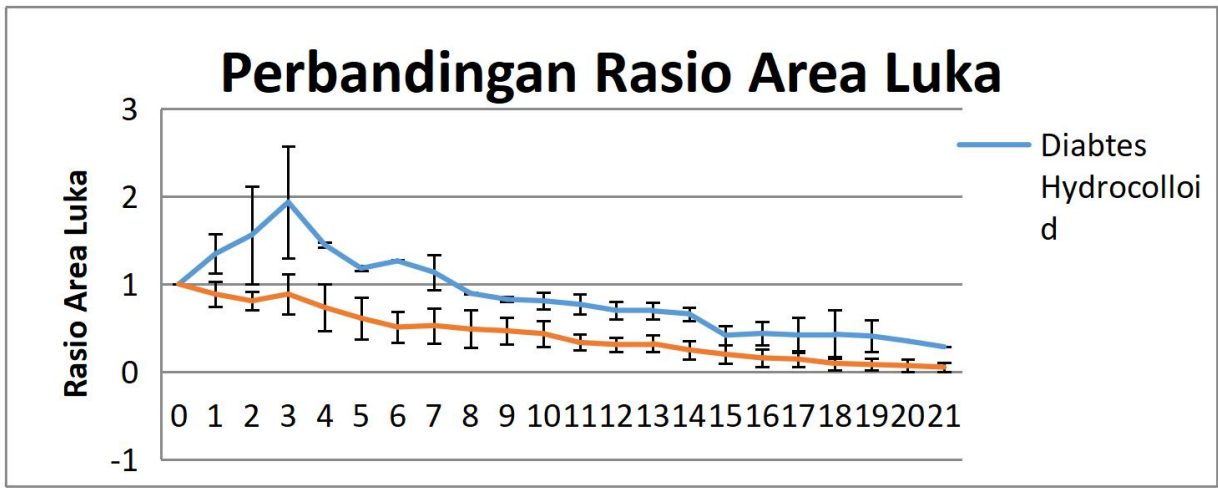

Gambar 2 menunjukkan grafik penyembuhan luka sampai hari ke-21. Berdasarkan grafik tesebut tampak bahwa dari hari pertama kelompok luka yang memperoleh perlakuan dressing gauze ukuran lukanya lebih kecil dibandingkan kelompok hydrocolloid. Hal ini 
mengindikasikan bahwa gauze lebih dapat digunakan untuk mempercepat penyembuhan luka. Perbedaan kedua kelompok ini diperkuat dengan perbedaan secara signifikan secara statistik $(\mathrm{p}=0.001)$.

Lebih lanjut, berdasarkan gambar 2 tersebut, tampak bahwa meski pun sama-sama mengalami penurunan ukuran luka namun penyembuhan luka pada kelompok hydrocolloid lebih lambat dibandingkan kelompok gauze. Itu bisa dibuktikan dari ukuran luka kelompok hydrocolloid yang lebih besar dan makin membesar bila dibandingkan dengan kelompok gauze sampai pada hari ke-3. Hal itu mengindikasikan bahwa terdapat perbedaan efek bagi penyembuhan luka. Perbedaan terdapat pada fase awal luka (fase inflamasi) hari ke-0 sampai 3, kelompok perlakuan hydrocolloid mengalami perluasan luka dan luka ukuran luka mulai mengecil mulai hari ke- 4. Perluasan ini kemungkinan terjadi karena sifat dari kulit tikus yang longgar (tidak seperti manusia) sehingga dressing hydrocolloid yang bersifat oklusif dan dapat menampung eksudat akan membuat luka menjadi terlalu basah yang menyebabkan perburukan kondisi luka. Menurut Wahyuningtyas (2018) salah satu yang merupakan hambatan paling utama dalam proses penyembuhan luka yakni satu diantaranya adalah kurangnya angiogenesis pada area granulasi luka. Kurangnya pembentukan pembuluh darah baru dapat menyebabkan nutrisi yang dibutuhkan dalam pembentukna kulit menjadi kurang. Kondisi ini diindikasikan terjadi pada perlakuan hydrocolloid yang diunjukkan dengan perbesaran ukuran luka di fase inflamasi dan luka lebih lambat menutup bila dibandingkan dengan perlakuan dengan gauze.

Luka pada perlakuan dengan menggunakan gauze menunjukkan kondisi yang lebih baik. Gauze yang bersifat non-oklusif membuat sirkulasi udara dapat terjadi dan kulit membuat kulit tetap lembab tetapi tidak terlalu basah sehingga tidak memperburuk kondisi kulit. Pertukaran udara tersebut mungkin menjadi keuntungan tersendiri pada penyembuhan luka, karena pada fase awal reaksi inflamasi, neutrophil dan makrofag masuk ke dalam jaringan yang mengalami luka dan sel -sel ini memproduksi Reactive Oxygen Species yang dapat memberikan efek menguntungkan maupun merugikan. Stres oksidatif menggambarkan ketidakseimbangan antara prooksidan atau radikal bebas dan antioksidan yang berfungsi mempertahankan kondisi terhadap kerusakan jaringan. Stres oksidatif terjadi apabila produksi Reactive Oxygen Species yang terjadi melebihi antioksidan yang ada sebagai pertahanan intrinsik. Reactive Oxygen Species dan Reactive Nitrogen Species adalah bagian penting dalam proses penyembuhan luka dan harus dalam kondisi homeostasis agar tidak menimbulkan stres oksidatif. Kondisi berlebihan dari $\mathrm{O}_{2}$ - pada luka dan kehadiran $\mathrm{NO}$ yang berlebihan meningkatkan resiko stres oksidatif sehingga mengganggu proses penyembuhan luka. Stres oksidatif berperan pada fase inflamasi, proliferasi dan remodeling dengan cara meningkatkan angiogenesis dan mempengaruhi sel-sel yang lain termasuk sel endotel dalam mengeluarkan NO (Lindley et.al. 2016, Privat-Maldonado et.al 2019).

Penelitian ini merupakan upaya untuk mencari jenis dressing yang sesuai untuk perwatan luka diabetes, terutama untuk penutup luka pada penelitian menggunkan hewan coba, namun ada kekurangan, yaitu evaluasi penyembuhan luka masih terbatas pada bersifat makroskopis. Penelitian selanjutnya perlu dilakukan sampai tahap remodeling penyembuhan luka dengan dukungan kajian secara mikroskopis histopatologis.

\section{Simpulan dan Saran}

\section{Simpulan}

Hasil dari penelitian ini menunjukkan bahwa perlakuan dressing hydrocolloid dan gauze memiliki dampak yang berbeda bagi penyembuhan luka, walaupun keduanya membantu dalam proses penyembuhan luka.

\section{Saran}

Perlu dilakukan sampai tahap remodeling penyembuhan luka dengan dukungan kajian secara mikroskopis histopatologis pada penelitian yang akan dilanjutkan kedepannya. 


\section{Daftar Pustaka}

Ashary, K. L. (2019). Kadar Glukosa Darah dan Tekanan Darah pada Anggota PROLANIS di Puskesmas Somagede Kabupaten Banyumas. Jaringan Laboratorium Medis, 1(2), 91-97.

Darmawati S et.al. (2021). Accelerated Healing of Chronic Wounds under a Combinatorial Therapeutic Regimen Based on Cold Atmospheric Plasma Jet Using Contact and Noncontact Styles. Jurnal Plasma Medicine, 11 (2). doi:10.1615/PlasmaMed.2021039083.

Gunardi. (2020). Profil HbA1c , Kolesterol dan Trigliserida pada Pasien Diabetes Mellitus Tipe 2 Profile of HbA1c, Cholesterol and Triglyceride in Type 2 Diabetes Mellitus. Jaringan Laboratorium Medis, 02(02), 89-93.

Hunt TK, et.al. (2000). Physiology of wound healing. Jurnal Adv Skin Wound Care, 13(2)(Suppl.): 6-11. [PMID: 11074996].

Imawati, H. (2020). Gambaran Kadar Glukosa , Tekanan Darah , dan Profil Lipid pada Pasien Prolanis DM Hipertensi. Jaringan Laboratorium Medis, 02(02), $61-67$.

Kartika, R. W. (2015). Perawatan Luka Kronis Dengan Modern Dressing. Cermin Dunia Kedokteran, 42(7). 546-550.

Landen et.al. (2016). Transition from inflammation to proliferation: a critical step during wound healing. Cell. Mol. Life Science, 73 (20):3861-3885.

doi 10.1007/s00018-016-2268-0.

Lindley et.al. (2016). Biology and Biomarkers for Wound Healing. Plast Reconstr Surg.; 138 (3): 18S-28S. doi:10.1097/PRS.0000000000002682

Oguntibeju O.O. (2019). Medicinal plants and their effects on diabetic wound healing. Vet World, 12(5):653-663. doi: 10.14202/vetworld.2019.653-663.

Privat-Maldonado et.al. (2019). ROS from Physical Plasmas: Redox Chemistry for Biomedical Therapy. Hindawi. Oxidative Medicine and Cellular Longevity. Article ID 9062098. https://doi.org/10.1155/2019/9062098.

Rivera AE \& Spencer JM. (2007). Clinical aspects of full-thickness wound healing. Clin Dermatol 25 :3948. [http://dx.doi.org/10.1016/j.clindermatol.2006.10.001] [PMID: 17276200].

Strecker-McGraw MK, et.al. (2007) Soft tissue wounds and principles of healing. EmergMedClinNorthAm;25(1):1-22.

[http://dx.doi.org/10.1016/j.emc.2006.12.002] [PMID: 17400070].

Tan et al. (2019). Improvement of diabetic wound healing by topical application of Vicenin-2 hydrocolloid film on Sprague Dawley rats. BMC Complementary and Alternative Medicine, 20. https://doi.org/10.1186/s12906-018-2427-y.

Wahyuningtyas ES, et al. (2018). Comparative Study on Manuka and Indonesian Honeys to Support the Application of Plasma Jet during Proliferative Phase on Wound Healing. Clinical Plasma Medicine, 12, 1-9.

Wahyuningtyas ES, et al., (2018). Comparative Study on Manuka and Indonesian Honeys to Support the Application of Plasma Jet during Proliferative Phase on Wound Healing. Clinical Plasma Medicine, 12, 1-9. 